\title{
Penentuan sistem antrean dengan pertimbangan biaya dan kontrol kedatangan pasien: Studi kasus di Puskesmas Ungaran Semarang
}

\author{
Albert Hosea Santoso ${ }^{1}$ (D) , Hanifa Reygina Fajrin ${ }^{1}$ (D), Akhmad Sultoni ${ }^{1}$ (D), Dwi Ertiningsih ${ }^{1 *}$ (i) \\ ${ }^{1}$ Department of Mathematics, Universitas Gadjah Mada, Yogyakarta, Indonesia \\ * Corresponding Author. E-mail: dwi_ertiningsih@ugm.ac.id
}

\begin{tabular}{ll}
\hline \multicolumn{1}{c}{ ARTICLE INFO } & \multicolumn{1}{c}{ ABSTRACT } \\
\hline Article History: & Penelitian ini bertujuan untuk menentukan sistem antrean yang efektif dengan mempertim- \\
Received: 30 Oct. 2020 & bangkan biaya dan kontrol kedatangan pasien pada fasilitas kesehatan: Puskesmas Ungaran, \\
Revised: 02 Nov. 2020 & Semarang. Penelitian ini menggunakan data kuantitatif berupa waktu kedatangan pasien, waktu \\
Accepted: 20 Jan. 2021 & pelayanan pasien, jumlah pasien, dan jumlah pelayan. Tahapan-tahapan yang dilakukan dalam \\
Keywords: & penelitian ini adalah menganalisis steady state dari sistem antrean, ukuran kinerja pada sistem \\
Model M/M/S, & antrean, keefektifan sistem antrean dengan pertimbangan biaya (cost), dan keefektifan sistem \\
Analisis keefektifan, & antrean dengan pertimbangan kontrol pada kedatangan pasien. Hasil analisis sistem antrean \\
Kontrol penerimaan, & pada kedatangan pasien di loket pendaftaran, ruang dokter, dan loket apotek merupakan pro- \\
Threshold optimal. & ses Poisson, sedangkan pelayanan pasien berdistribusi eksponensial. Jumlah pelayan dan biaya \\
& yang efektif pada masing-masing sistem antrean adalah dua pelayan dengan biaya Rp59.513 \\
& pada loket pendaftaran; empat pelayan dengan biaya Rp141.864 pada ruang dokter; dan satu \\
& pelayan dengan biaya Rp23.885 pada loket apotek. Rerata jumlah pasien dalam antrean dan \\
& sistem antrean masing-masing adalah dua pasien dan lima pasien. Rerata waktu pasien me- \\
& nunggu di dalam antrean maupun sistem antrean adalah 1,937 menit dan 8,883 menit. Lebih \\
& lanjut, ketika dilakukan kontrol pada kedatangan pasien, maka jumlah pasien yang diterima akan \\
& meningkat ketika biaya yang dibutuhkan puskesmas dalam menerima pasien diperbesar.
\end{tabular}

Scan me:

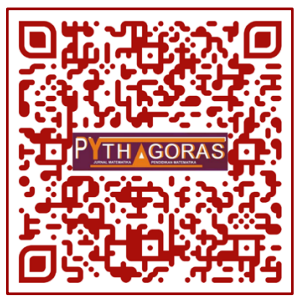

The study aimed to determine an effective queuing system by considering costs and control of patient arrival at a health facility: Puskesmas Ungaran, Semarang, Indonesia. The study used quantitative data in patient arrival time, patient service time, number of patients, and number of servants. The stages carried out were analyzing the steady-state of the queuing system, performance measures of the queuing system, the effectiveness of the queuing system by considering costs, and the effectiveness of the queuing system by considering control of patient arrival. The result of the queuing system analysis at the arrival of the patient at the registration counter, doctor's office, and pharmacy counter was a Poisson process, while patient service has an exponential distribution. The number of servants and costs in each of the effective queuing systems was two servants with costs 59,513 IDR at the registration counter; four servants with costs 141,864 IDR at the doctor's office; and one servant with costs 23,885 IDR at the pharmacy counter. The average number of patients in the queue and queue system was two patients and five patients, respectively. The average time for patients to wait in the queue and queue system was 1.937 minutes and 8.883 minutes. Furthermore, when the patient arrival was controlled, the number of patients accepted will increase when the health center's costs to receive patients were increased.

This is an open access article under the CC-BY-SA license

\section{How to Cite:}

Santoso, A. H., Fajrin, H. R., Sultoni, A., \& Ertiningsih, D. (2020). Penentuan sistem antrean dengan pertimbangan biaya dan kontrol kedatangan pasien: Studi kasus di Puskesmas Ungaran Semarang. Pythagoras: Jurnal Pendidikan Matematika, 15(2), 165-177. https://doi.org/10.21831/pg.v15i2.35403

https://doi.org/10.21831/pg.v15i2.35403 


\section{PENDAHULUAN}

Indonesia merupakan negara dengan populasi terpadat keempat di dunia, dengan jumlah total populasi Indonesia pada tahun 2019 sekitar 268 juta jiwa (Badan Pusat Statistik, 2020). Dengan populasi yang begitu besar tentu saja sangat berdampak pada berbagai sektor kehidupan. Salah satu dampaknya terhadap fasilitas yang digunakan bersama, seperti tempat hiburan-olahraga, tempat pelayanan kesehatan, tempat pendidikan, tempat makan, tempat pemenuhan ekonomi, dan lain sebagainya. Namun karena keterbatasan kapasitas pelayanan, pelanggan yang datang tidak bisa langsung dilayani melainkan harus menunggu giliran dalam sebuah barisan yang dikenal dengan "antrean". Menurut lqbal (2011), antrean terdapat pada kondisi apabila obyek-obyek menuju suatu area untuk dilayani, namun kemudian menghadapi keterlambatan disebabkan oleh mekanisme pelayanan mengalami kesibukan. Antrean timbul karena adanya ketidakseimbangan antara yang dilayani dengan pelayanannya. Ketika dibiarkan akan menimbulkan efek yang negatif, baik dari sisi lamanya waktu menunggu untuk dilayani, serta menurunkan kenyamanan pelanggan. Hal ini menjadi perhatian serius oleh Agner Krarup Erlang, sehingga pada tahun 1913, Erlang menjelaskan mengenai teori antrean walaupun masih dalam konteks fasilitas telepon (Mehandiratta, 2011). Kemudian di dalam buku Heizer dan Render (2011) teori antrean diartikan sebagai ilmu pengetahuan tentang bentuk antrean dan merupakan orang-orang atau barang dalam barisan yang sedang menunggu untuk dilayani.

Sistem antrean menurut lbe (2013) merupakan model fasilitas layanan dimana pelanggan datang untuk menerima layanan dan kemudian pergi setelah mereka dilayani. Ketika jumlah pelayan terlalu banyak maka akan memerlukan biaya yang besar, sebaliknya ketika jumlah pelayan kurang berakibat terjadi antrean dalam waktu yang lama sehingga timbul biaya (Robiati, 2015). Oleh karena itu, teori antrean mempunyai tujuan untuk meminimalkan waktu tunggu dan biaya yang dikeluarkan. Lakshmi dan lyer (2013) menyatakan bahwa teori antrean merupakan alat yang mudah diterapkan, karena membutuhkan sedikit data, relatif sederhana formulasi perhitungannya, dan cepat dalam penggunaannya.

Salah satu penerapan teori antrean dalam kehidupan sehari-hari adalah dalam fasilitas kesehatan. Oleh karena itu, dalam penelitian ini akan dibahas analisis sistem antrean pada fasilitas kesehatan, khususnya pada pelayanan pasien di puskesmas. Alasan pemilihan puskesmas sebagai objek penelitian karena fasilitas kesehatan ini hampir ada di seluruh penjuru Indonesia, bahkan sampai tingkat kecamatan. Hingga Desember 2018, jumlah keseluruhan puskesmas di Indonesia tercatat mencapai 9.993 (Kementerian Kesehatan Republik Indonesia, 2019). Puskesmas sudah menjadi fasilitas kesehatan terdepan masyarakat Indonesia menurut Kementerian PPN/Bappenas (2018). Di sisi lain, apabila jumlah masyarakat Indonesia dibandingkan dengan jumlah puskesmas yang tersedia, maka satu puskesmas melayani $26.980 \mathrm{jiwa}$. Hal ini mengakibatkan sering terjadinya penumpukan pasien. Maka dari itu, dibutuhkan suatu tata kelola yang baik dari pihak puskesmas untuk mengatasi antrean yang berkepanjangan, yaitu berupa penentuan sistem antrean yang sesuai.

Upaya untuk mengatasi antrean yang berkepanjangan tersebut dibuktikan dengan adanya penelitian-penelitian yang dilakukan pada beberapa puskesmas di Indonesia. Penelitian Nasution dan Mutia (2017) terkait analisis sistem antrean pada loket pendaftaran pasien di Puskesmas Padang Pasir Kecamatan Padang Barat. Mereka menggunakan metode statistik dan teori antrean $\mathrm{M} / \mathrm{M} / \mathrm{c}$ untuk menghitung antrean sistem pelayanan yang optimal berdasarkan tingkat kedatangan dan tingkat pelayanan. Berikutnya, penelitian Wati (2017) terkait sistem antrean pelayanan pasien pada Puskesmas Kelurahan Setiabudi Jakarta Selatan dengan menggunakan metode waiting line. Selain itu, penelitian Sofyan et al. (2019) mengenai penerapan sistem antrean pada fasilitas pelayanan pada loket pengambilan obat di Puskesmas Kecamatan Kuala dengan menggunakan simulasi arena.

Penelitian lainnya, yaitu Robiati (2015) telah meneliti tentang sistem antrean di Puskesmas Ungaran, Semarang, namun penelitian tersebut masih terbatas pada model sistem antrean yang efektif tanpa pertimbangan biaya. Penelitian Robiati ini akan dikembangkan oleh penulis dengan menentukan sistem antrean yang efektif dengan pertimbangan biaya (cost). Selain itu, Ertiningsih et al. (2018) telah menerapkan metode admission control dalam menentukan keefektifan sistem antrean. Asumsi yang digunakan dalam pemodelan admission control adalah dengan menambahkan ambang batasan (threshold) penerimaan pelanggan yang dapat bergabung ke dalam sistem antrean. Hasil penelitian Ertiningsih et al. (2018) menunjukkan bahwa ambang batas penerimaan pelanggan (threshold) dapat ditentukan dengan tingkat konvergensi yang lebih cepat dan nilainya lebih eksplisit dibandingkan dengan metode yang sudah ada sebelumnya, namun masih belum diterapkan pada masalah nyata. Dengan demikian, dalam penelitian ini penulis juga akan menerapkan metode admission control yang dilandaskan pada pene- 
litian dari Ertiningsih et al. (2018) dalam menentukan keefektifan sistem antrean di Puskesmas Ungaran, Semarang untuk mengurangi antrean berkepanjangan.

Berdasarkan urgensi dan latar belakang penelitian yang telah dikemukakan, maka peneliti tertarik untukmelakukan analisis lebih lanjut yaitu dengan mempertimbangkan biaya dan kontrol penerimaan pasien menggunakan data penelitian Robiati (2015), sehingga diharapkan diperoleh sistem antrean yang lebih efektif. Dengan demikian tujuan dari penelitian ini adalah untuk menentukan sistem antrean yang efektif dengan mempertimbangkan biaya dan kontrol penerimaan pasien pada sistem antrean di fasilitas kesehatan, Puskesmas Ungaran, Semarang.

\section{METODE}

Penelitian ini berkaitan dengan sistem antrean pada fasilitas kesehatan. Adapun langkah-langkah dalam penelitian ini adalah dengan melakukan studi pustaka mengenai teori antrean, aplikasi teori antrean, serta sistem manajemen antrean di fasilitas kesehatan. Kemudian pengambilan data sekunder yang telah didapatkan dalam studi pustaka. Langkah selanjutnya menganalisis data sekunder tersebut yang meliputi analisis steady state, analisis ukuran kinerja pada sistem antrean, analisis keefektifan sistem antrean dengan pertimbangan biaya (cost), dan analisis keefektifan sistem antrean dengan pertimbangan kontrol.

\section{Jenis Data}

Jenis data yang digunakan adalah data kuantitatif. Menurut Kabir (2016), data kuantitatif adalah data yang dapat dihitung secara matematis. Data kuantitatifyang digunakan terdiri dari waktu kedatangan pelanggan, waktu selesai pelayanan pelanggan, jumlah pelanggan, jumlah pelayan, dan jumlah sistem antrean. Objek penelitian adalah sistem antrean di Puskesmas Ungaran, Semarang yang terdiri dari sistem antrean pada loket pendaftaran, ruang dokter, loket apotek. Karena objek penelitian adalah sistem antrean puskesmas, maka yang dimaksud dengan pelanggan adalah pasien (orang yang berobat). Selain itu pelayan di penelitian ini adalah pelayan pada loket pendaftaran, ruang dokter, dan apotek. Waktu pelayanan dimulai dari jam 07:30 WIB sampai dengan jam 12:00 WIB, sehingga waktu kerja (penelitian) selama 270 menit.

\section{Pengambilan Data Sekunder}

Dalam penelitian ini menggunakan data sekunder dikarenakan tidak memungkinkan untuk melakukan pengambilan data langsung pada fasilitas kesehatan selama masa pandemi COVID-19. Data sekunder yang digunakan adalah hasil penelitian Robiati (2015) di Puskesmas Ungaran, Semarang. Data tersebut dipilih karena datanya lengkap dan analisis yang telah dilakukan masih sebatas efisiensi sistem antrean yang belum mempertimbangkan faktor biaya. Tabel 1 memuat data sekunder dari penelitian Robiati (2015) di Puskesmas Ungaran, Semarang.

Tabel 1. Data sistem antrean di Puskesmas Ungaran, Semarang (Robiati, 2015)

\begin{tabular}{llll}
\hline Data & Loket pendaftaran & Ruang dokter & Loket apotek \\
\hline Distribusi kedatangan & Poisson & Poisson & Poisson \\
Distribusi pelayanan & Eksponensial & Eksponensial & Eksponensial \\
Laju kedatangan pasien (per menit) & 0,474 & 0,519 & 0,496 \\
Laju pelayanan (per menit) & 0,618 & 0,192 & 8,418 \\
Waktu Kerja (menit) & 270 & 270 & 270 \\
\hline
\end{tabular}

\section{Analisis Data Sekunder}

Sebagaimana dalam buku Fundamental of Queueing Theory (Shortle et al., 2018) bahwa karakteristik dasar sistem antrean terdiri dari enam komponen, yaitu pola kedatangan pelanggan, pola pelayanan, jumlah pelayan dan saluran layanan, kapasitas sistem, disiplin antrean, dan jumlah tahapan layanan. Untuk menentukan karakteristik yang ada pada data sekunder yang diperoleh, maka dilakukan analisis data sebagai berikut.

\section{Analisis steady state}

Diasumsikan bahwa laju effectiveness dari sistem antrean diberikan sebagai berikut.

$$
\rho=\frac{\lambda}{\mu}<1
$$


dengan $\lambda$ dan $\mu$ masing-masing menyatakan laju kedatangan pelanggan dan pelayanan. Persamaan (1) merupakan syarat kestabilan dari sistem antrean, yaitu ketika laju pelanggan yang datang kurang dari laju pelayanan, maka sistem antrean stabil (tidak melebihi kemampuan pelayanan). Selain itu, jika Persamaan 1 tidak terpenuhi, maka sistem tidak stabil (terjadi ledakan pelanggan). Kemudian Ketika pelayan ditambahkan sedemikian sehingga jumlahnya lebih dari satu, maka laju effectiveness $\rho_{k}$ adalah sebagai berikut.

$$
\rho_{k}=\frac{\lambda}{k \times \mu}
$$

dengan parameter $k$ menunjukkan banyaknya pelayan dalam sistem antrean.

\section{Analisis ukuran kinerja pada sistem antrean}

Merujuk Tiwari et al. (2015), ukuran kinerja yang dianalisis dalam penelitian ini terdiri dari empat komponen, yaitu rerata jumlah pelanggan dalam sistem antrean $(L s)$, rerata jumlah pelanggan dalam antrean $(L q)$, rerata waktu menunggu dalam sistem antrean $(W s)$, dan rerata waktu menunggu dalam antrean $(W q)$. Rata-rata jumlah pelanggan dalam sistem antrean $(L s)$, yaitu banyaknya pelanggan yang mengantre ditambah banyaknya pelanggan yang sedang dilayani, dengan formula perhitungan pada Persamaan 3.

$$
L s=\frac{\rho}{1-\rho} \text { atau } L s=\frac{\lambda}{\mu-\lambda}
$$

Rata-rata waktu menunggu untuk seorang pelanggan dalam sistem antrean $(W s)$, yaitu waktu yang dihabiskan selama mengantre ditambah waktu yang dihabiskan saat sedang dilayani, dengan formula perhitungan pada Persamaan 4.

$$
W s=\frac{1}{\mu-\lambda}
$$

Rata-rata jumlah pelanggan yang mengantre $(L q)$, dengan formula perhitungan pada Persamaan 5.

$$
L q=\frac{\lambda^{2}}{\mu(\mu-\lambda)}
$$

Rata-rata waktu menunggu seorang pelanggan untuk mengantre, dengan formula perhitungan pada Persamaan 6.

$$
W q=\frac{\lambda}{\mu(\mu-\lambda)}
$$

\section{Analisis keefektifan sistem antrean dengan pertimbangan biaya (cost)}

Setelah diperoleh ukuran kinerja sistem antrean, selanjutnya dengan asumsi biaya yang diberikan, maka dapat ditentukan sistem antrean yang efektif. Berikut formula perhitungan nilai biaya dari sistem antrean.

$$
\text { Total Biaya }=L s \times B c+k \times B_{k}
$$

dengan $L_{s}, B c, k$ dan $B_{k}$ masing-masing menyatakan jumlah pasien dalam sistem antrean, biaya (kerugian) pasien ketika masuk sistem antrean, jumlah pelayan dalam sistem antrean, dan biaya yang perlu dikeluarkan untuk membayar pelayan. Menentukan keefektifan sistem antrean dapat dilakukan dengan pengujian beberapa perlakuan. Semua perlakuan dihitung total biayanya, kemudian dibandingkan mana yang memiliki total biaya terkecil. Jika perlakuan memiliki nilai biaya terkecil maka sistem tersebut yang lebih efektif dibandingkan yang lain.

\section{Analisis keefektifan sistem antrean dengan pertimbangan kontrol}

Selain analisis keefektifan sistem antrean dengan pertimbangan biaya, juga diterapkan analisis keefektifan dengan pertimbangan kontrol. Kontrol yang dimaksud di sini adalah kontrol pada penerimaan pasien (admission control), dimana parameter-parameter yang digunakan adalah $c_{r}, c_{h}, \gamma$ yang masing-masing menyatakan biaya penolakan, biaya holding, dan suatu konstanta real. Analisis ini bertujuan untuk menentukan batas penerimaan (threshold) atau bisa diistilahkan dengan daya tampung dari sistem antrean. Batas penerimaan tersebut bisa disimbolkan dengan $\delta$. Lebih lanjut, dengan mengetahui $\delta$, pelaku kebijakan bisa memprediksi biaya yang dibutuhkan ketika akan meningkatkan kapasitas sistem antrean. Adapun perhitungan $\delta$ merujuk pada Ertiningsih et al. (2018), dengan langkah awalnya adalah menentukan $\gamma^{u}$ (upper) dan $\gamma^{l}$ (lower). Parameter $\gamma^{u}$ maksudnya adalah $\gamma$ upper yang nanti digunakan dalam penentuan nilai $\delta$ dari arah atas, dan parameter $\gamma^{l}$ maksudnya adalah $\gamma$ lower 
yang nantinya digunakan dalam penentuan nilai $\delta$ dari arah bawah. Nilai $\delta$ diperoleh ketika $\delta$ atas dan $\delta$ bawah bernilai sama. Nilai $\delta$ inilah yang merupakan batasan penerimaan pelanggan dari sistem antrean. Berikut merupakan algoritma untuk mencari nilai $\gamma^{u}$ dan $\gamma^{l}$.

\section{Algoritma 1. Penentuan nilai $\gamma^{\boldsymbol{u}}$}

- Jika $c_{r}<c_{h} / \mu$, maka dipilih $\gamma^{u}=c_{h} /(3 \mu)$. Selanjutnya, $\delta_{1}^{u}=\delta^{*}=0$ adalah nilai optimal. Dengan kata lain, sistem akan optimal dengan selalu menolak pelanggan.

- Jika $c_{r} \geq c_{h} / \mu$, dan $\frac{c_{r}}{5}<\left\{\frac{c_{h}+\lambda c_{r}}{3}, \frac{c_{h}}{2 \mu}\right\}$, maka dipilih $\gamma^{u}=\left\{\frac{c_{h}+\lambda c_{r}}{3}, \frac{c_{h}}{2 \mu}\right\}$

Selanjutnya, $\delta_{1}^{u}=1$ dan $\delta^{*} \in\{0,1\}$.

- Jika $\frac{c_{r}}{5} \geq\left\{\frac{c_{h}+\lambda c_{r}}{3}, \frac{c_{h}}{2 \mu}\right\}$, maka dipilih $\gamma^{u}=\left\{\frac{c_{h}}{3 \mu-2 \lambda}, \frac{c_{h}}{2 \mu}\right\}$

\section{Algoritma 2. Penentuan nilai $\gamma^{l}$}

- Jika $\frac{c_{r}}{5}>\frac{c_{h}}{2(\mu-\lambda)}$, maka dipilih $\gamma^{l}=\frac{c_{h}}{2(\mu-\lambda)}$

- Jika $\frac{c_{r}}{5} \leq \frac{c_{h}}{2(\mu-\lambda)}$ dan $\frac{c_{h}}{2 \mu} \leq \frac{c_{r}}{3}$, maka dipilih $\gamma^{l} \geq\left\{\frac{c_{h}}{2 \mu}, \frac{c_{h}+\lambda c_{r}}{3}\right\} ; \gamma^{l}>\frac{c_{r}}{5}$

diperoleh $\delta_{1}^{l}=1$.

- Jika $\frac{c_{r}}{3} \leq \frac{c_{h}}{2 \mu}$, maka dipilih $\gamma^{l}=\frac{c_{h}}{2 \mu}$

diperoleh $\delta_{1}^{l}=0$.

Setelah diperoleh $\gamma^{u}$ dan $\gamma^{l}$, langkah selanjutnya adalah mencari nilai parameter $v_{n}$ yang menyatakan fungsi nilai optimal pada perhitungan ke- $n$ dengan $n=1,2,3, \ldots$. Sama seperti $\gamma$, parameter $v_{n}$ juga dibagi menjadi dua, pertama pencarian fungsi upper yang disimbolkan dengan $v_{n}^{u}$ dan kedua pencarian fungsi lower yang disimbolkan dengan $v_{n}^{l}$. Terdapat formula khusus untuk $n=0$ dan $n=1$. Berikut merupakan formula perhitungan parameter $v_{0}^{u}$ dan $v_{0}^{l}$.

$$
\begin{aligned}
& v_{0}^{u}=\gamma^{u}(x+1)^{2}, x \in S \\
& v_{0}^{l}=\gamma^{u}(x+1)^{2}, x \in S .
\end{aligned}
$$

Sedangkan formulasi perhitungan parameter $v_{1}^{u}$ dan $v_{1}^{l}$ untuk $x \in S, i \in\{u, l\}$ adalah sebagai berikut:

$$
v_{1}^{i}(x)=\left\{\begin{array}{lr}
\gamma^{i}+\lambda c_{r}, & x=0, \delta_{1}^{i}=0 \\
\gamma^{i}(1+3 \lambda), & x=0, \delta_{1}^{i} \geq 0 \\
c_{h} x+\gamma^{i}\left(x^{2}+4 \lambda x+4 \lambda\right), & 1 \leq x \leq \delta_{1}^{i} \\
c_{h} x+\lambda c_{r}+\gamma^{i}\left(x^{2}+2 \lambda x+\lambda\right), & x \geq \delta_{1}^{i}
\end{array}\right.
$$

Selanjutnya untuk menentukan $v_{n+1}^{i}$ dengan $n \in\{1,2,3, \ldots\}$, menggunakan formula perhitungan sebagai berikut:

$$
\begin{aligned}
v_{n+1}^{i}(x) & =c_{h}(x)+\mu v_{n}^{i}\left((x-i)^{+}\right)+\lambda \min \left\{v_{n}^{i}(x+1), c_{r}+v_{n}^{i}(x)\right\} \\
& =c_{h}(x)+\mu v_{n}^{i}\left((x-i)^{+}\right)+\lambda v_{n}^{i}(x)+\lambda \min \left\{v_{n}^{i}(x+1)-v_{n}^{i}(x), c_{r}\right\}
\end{aligned}
$$

Langkah selanjutnya adalah pencarian batas (threshold) $\delta_{n+1}^{i}$, menggunakan formula perhitungan sebagai berikut:

$$
\delta_{n+1}^{i}= \begin{cases}\left\{v_{n}^{i}(x+1)-v_{n}^{i}(x)>c_{r}\right\}, & \text { jika } \sup _{x}\left(v_{n}^{i}(x+1)-v_{n}^{i}(x)\right)>c_{r} \\ \infty, & \text { yang lainnya }\end{cases}
$$

Langkah terakhir adalah menentukan $\delta$ yang bernilai $n$, yaitu $\delta^{u}=\delta^{l}=n$.

\section{HASIL PENELITIAN}

Sebagaimana telah dibahas pada bagian pendahuluan, dalam penelitian ini dibahas analisis sistem antrean pada fasilitas kesehatan di Puskesmas. Dalam menganalisis sistem antrean di puskesmas, digunakan studi kasus terhadap Puskesmas Ungaran, Semarang. Data sekunder yang digunakan merupakan hasil penelitian Robiati 
(2015) yang disajikan pada Tabel 1. Robiati (2015) menyimpulkan bahwa sistem antrean di Puskesmas Ungaran, Semarang akan efisien jika menggunakan model $\mathrm{M} / \mathrm{M} / 1$ di loket pendaftaran, model $\mathrm{M} / \mathrm{M} / 7$ di ruang dokter, dan model $\mathrm{M} / \mathrm{M} / 1$ di loket apotek. Hal ini berarti bahwa sistem antrean mengikuti pola kedatangan yang berdistribusi Poisson sedangkan waktu pelayanan berdistribusi eksponensial, dengan jumlah pelayan meliputi satu petugas di loket pendaftaran, tujuh dokter di ruang dokter, dan satu petugas di loket apotek. Hasil tersebut merupakan analisis keefektifan sistem antrean dengan hanya dengan menggunakan data rate kedatangan dan rate pelayanan.

Untuk melengkapi hasil yang sudah diperoleh Robiati (2015), dalam penelitian ini dilakukan analisa pada data sekunder tersebut dengan dua perlakuan yang mempertimbangkan biaya yang dikeluarkan. Dua perlakuan tersebut adalah sebagai berikut: pertama, dilakukan analisis keefektifan sistem antrean dengan pertimbangan biaya; kedua, menganalisis keefektifan sistem antrean dengan menambahkan kontrol atau kendali pada penerimaan pasien.

\section{Analisis Keefektifan Sistem Antrean dengan Pertimbangan Biaya}

Langkah awal dalam menganalisis optimasi sistem antrean dengan pertimbangan biaya adalah menentukan asumsi biaya yang dikeluarkan. Biaya merupakan uang yang dibutuhkan atau dikeluarkan baik dari pengelola puskesmas maupun dari pelanggan/pasien selama masuk di antrean. Biaya pengelola puskesmas diperhitungkan dari asumsi gaji pelayan di loket pendaftaran, dokter di ruang dokter, dan pelayan di loket apotek. Diasumsikan pelayan di loket pendaftaran dan loket apotek, serta dokter merupakan PNS golongan III. Gaji rata-rata PNS golongan III adalah Rp3.688.200 per bulan berdasarkan data dari Sekretariat Kabinet Republik Indonesia (2019), sehingga rerata biaya per menit untuk pegawai puskesmas adalah Rp85,38. Kemudian biaya yang dikeluarkan pasien ketika masuk dalam antrean merupakan biaya kerugian yang didapatkan pasien karena harus menghabiskan waktu untuk mengantre yang seharusnya waktu tersebut bisa mereka gunakan untuk bekerja. Dalam hal ini, biaya pasien bukan biaya membayar administrasi ataupun layanan di puskesmas. Diasumsikan bahwa biaya yang dikeluarkan pasien berdasarkan pendapatan yang diperoleh. Pendapatan pasien diasumsikan sama berdasarkan UMK/UMR di Kabupaten Semarang, Jawa Tengah, yaitu sebesar Rp2.229.880 per bulan. Oleh karena itu, rerata biaya per menitnya adalah Rp51,62.

Langkah kedua adalah menghitung kinerja sistem antrean di Puskesmas Ungaran, Kabupaten Semarang. Perhitungan kinerja dilakukan dengan memberikan beberapa perlakuan terhadap jumlah pelayan, baik ditambah maupun dikurangi. Data yang kami gunakan adalah data sekunder dari Robiati (2015) yang disajikan dalam Tabel 1. Laju effectiveness sistem antrean di loket pendaftaran, ruang dokter, dan loket apotek diberikan sebagai berikut.

\section{Loket Pendaftaran}

$$
\rho=\frac{\lambda}{k \times \mu}=\frac{0,474}{k \times 0,618}=\frac{0,767}{k}
$$

Dari perhitungan tersebut bisa diperoleh bahwa laju effectiveness di loket pendaftaran akan kurang dari satu untuk $k=1,2, \ldots$. Artinya perlakuan di loket pendaftaran bisa dimulai dengan jumlah pelayan sama dengan satu.

\section{Ruang Dokter}

$$
\rho=\frac{\lambda}{k \times \mu}=\frac{0,519}{k \times 0,192}=\frac{2,703}{k}
$$

Dari perhitungan tersebut bisa diperoleh bahwa laju effectiveness di ruang dokter akan kurang dari satu ketika nilai $k=3,4,5, \ldots$. Artinya perlakuan di ruang dokter bisa dimulai dengan jumlah pelayan sama dengan tiga.

Loket Apotek

$$
\rho=\frac{\lambda}{k \times \mu}=\frac{0,496}{k \times 8,418}=\frac{0,059}{k}
$$

Dari perhitungan tersebut bisa diperoleh bahwa laju effectiveness di loket apotek akan kurang dari satu Ketika nilai $k=1,2,3, \ldots$. Artinya perlakuan di loket apotek bisa dimulai dengan jumlah pelayan sama dengan satu.

Setelah mengetahui laju effectiveness pada setiap sistem antrean, kemudian dilanjutkan dengan menghitung kinerja sistem, baik rerata jumlah pelanggan dalam sistem antrean $(L s)$, rerata jumlah pelanggan dalam antrean $(L q)$, rerata waktu (satuan menit) menunggu dalam sistem antrean $(W s)$, dan rerata waktu (satuan menit) me- 
nunggu dalam antrean $(W q)$. Dengan data sekunder dari Robiati (2015) bisa dihitung kinerja sistem dengan bantuan aplikasi WinQSB, dan hasil perhitungan disajikan pada Tabel 2.

Tabel 2. Hasil perhitungan sistem antrean di puskesmas

\begin{tabular}{lcccccc}
\hline Lokasi & $\begin{array}{c}\text { Pelayan } \\
(k)\end{array}$ & $\begin{array}{c}L s \\
\text { (orang) }\end{array}$ & $\begin{array}{c}L q \\
\text { (orang) }\end{array}$ & $\begin{array}{c}W s \\
\text { (menit) }\end{array}$ & $\begin{array}{c}W q \\
\text { (menit) }\end{array}$ & $\begin{array}{c}\text { Laju effectiveness } \\
\left(\rho_{k}\right)\end{array}$ \\
\hline Loket & 1 & 4,150 & 3,344 & 8,333 & 6,715 & $76,699 \%$ \\
Pendaftaran & 2 & 0,962 & 0,156 & 1,932 & 0,314 & $38,350 \%$ \\
& 3 & 0,825 & 0,020 & 1,657 & 0,039 & $25,566 \%$ \\
\multirow{4}{*}{ Ruang Dokter } & 4 & 0,808 & 0,003 & 1,623 & 0,005 & $19,175 \%$ \\
& 3 & 10,724 & 8,005 & 20,544 & 15,336 & $90,104 \%$ \\
& 4 & 3,563 & 0,844 & 6,825 & 1,617 & $67,578 \%$ \\
& 5 & 2,924 & 0,205 & 5,602 & 0,393 & $54,063 \%$ \\
& 6 & 2,774 & 0,056 & 5,315 & 0,106 & $45,052 \%$ \\
& 7 & 2,734 & 0,015 & 5,237 & 0,029 & $38,616 \%$ \\
& 8 & 2,723 & 0,004 & 5,216 & 0,007 & $33,789 \%$ \\
& 1 & 0,060 & 0,003 & 0,126 & 0,007 & $5,892 \%$ \\
& 2 & 0,056 & 0,000 & 0,119 & 0,000 & $2,946 \%$ \\
& 3 & 0,056 & 0,000 & 0,119 & 0,000 & $1,964 \%$ \\
\hline
\end{tabular}

Pemilihan jumlah pelayanan di setiap sistem diberlakukan berbeda, 4 perlakuan untuk sistem di loket pendaftaran, 6 perlakuan di ruang dokter, dan 3 perlakuan di loket apotek. Jumlah perlakuan di masing-masing sistem tidak sama karena memperhatikan tingkat kesibukan yang tidak boleh lebih dari $100 \%$.

Langkah ketiga adalah menghitung keefektifan ketiga sistem antrean di Puskesmas Ungaran, Semarang. Pengukuran keefektifan sistem dilihat dari biaya paling minimum yang dikeluarkan. Penghitungan biaya menggunakan formula pada Persamaan 7. Berikut hasil perhitungan yang disajikan dalam Gambar 1.

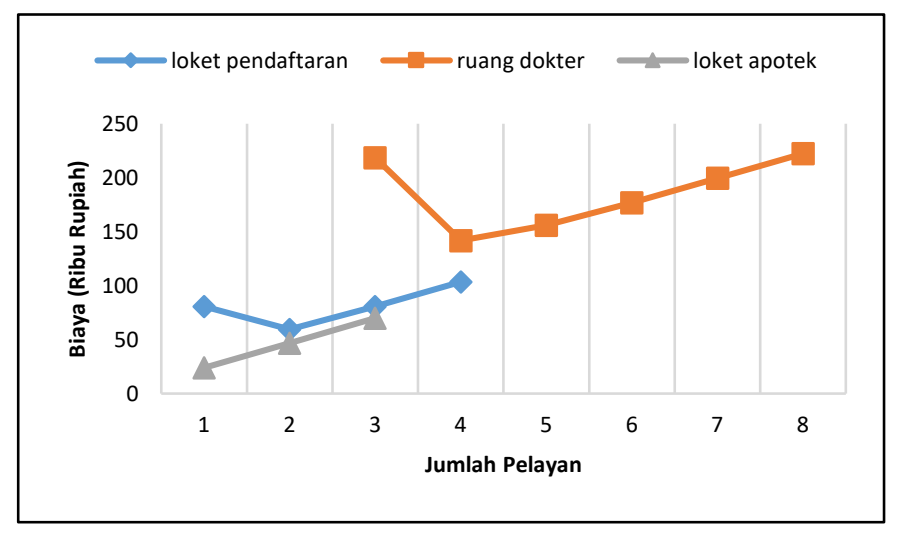

Gambar 1. Keefektifan ketiga sistem antrean pada Puskesmas Ungaran, Semarang

Pada analisis keefektifan sistem antrean dengan pertimbangan biaya, seperti pada Gambar 1 diperoleh bahwa sistem antrean dengan pertimbangan biaya di loket pendaftaran terdapat empat model, yaitu $M / M / 1$ dengan biaya Rp80.893, M/M/2 dengan biaya Rp59.513, M/M/3 dengan biaya Rp80.660, dan M/M/4 dengan biaya Rp103.476. Sehingga diperoleh sistem antrean yang paling efektif adalah model $\mathrm{M} / \mathrm{M} / 2$ dengan biaya 59.513 rupiah. Hal ini berarti loket pendaftaran disarankan menggunakan dua pelayan untuk meminimalkan biaya pengeluaran puskesmas dalam mengatasi antrean pasien (kedatangan pasien berdistribusi Poisson, pelayanan berdistribusi eksponensial) dengan biaya minimal sekitar Rp59.513 per hariannya.

Selanjutnya, di ruang dokter terdapat enam model, yaitu M/M/3 dengan biaya Rp218.622, M/M/4 dengan biaya Rp141.864, M/M/5 dengan biaya Rp156.016, M/M/6 dengan biaya Rp176.982, M/M/7 dengan biaya Rp199.467, dan M/M/8 dengan biaya Rp222.367. Dengan demikian diperoleh sistem antrean yang paling efektif adalah model M/M/4 dengan biaya Rp141.864. Analog dengan sistem antrean di loket pendaftaran, ruang dokter disarankan menggunakan empat pelayan, guna meminimalkan biaya pengeluaran puskesmas dalam mengatasi 
antrean dengan kedatangan pasien yang berdistribusi Poisson dan pelayanan berdistribusi eksponensial, dengan biaya sekitar 141.864 rupiah per harinya.

Analisis yang sama dilakukan di loket apotek, sehingga diperoleh tiga model, $M / M / 1$ dengan biaya Rp23.885, $\mathrm{M} / \mathrm{M} / 2$ dengan biaya Rp46.891, dan $\mathrm{M} / \mathrm{M} / 3$ dengan biaya Rp69.942. Dengan demikian, sistem antrean paling efektif menggunakan model M/M/1 dengan biaya Rp23.885. Hal ini berarti sistem antrean di loket apotek akan lebih efektif jika menggunakan satu pelayan, karena biaya pengeluaran puskesmas dalam mengatasi antrean dengan kedatangan pasien berdistribusi Poisson dan pelayanan berdistribusi eksponensial paling minimum dibandingkan model yang lain, yaitu sebesar Rp23.885.

\section{Analisis Keefektifan Sistem Antrean dengan Pertimbangan Kontrol Penerimaan Pasien}

Pasien tidak bisa ditampung atau diterima semua dalam waktu yang sama di ruang puskesmas, karena ruang puskesmas memiliki kapasitas yang terbatas. Apalagi kondisi pandemi saat ini, setiap orang dianjurkan untuk menjaga jarak aman satu sama lain. Akibatnya daya tampung ruang puskesmas semakin kecil. Hal tersebut menjadi fokus penelitian untuk memodelkan suatu masalah antrean dalam mengatasi hal tersebut. Asumsi yang digunakan adalah adanya admission control pada kedatangan pasien. Admission control merupakan pengontrolan jumlah penerimaan pasien di puskesmas yaitu apabila kapasitas ruangan sudah terpenuhi, maka pasien yang datang akan ditolak masuk ke dalam puskesmas dan akan diterima ketika ada pasien yang sudah selesai di layani. Model ini masih terbatas pada sistem antrean M/M/1, sebagaimana didasarkan dalam artikel Ertiningsih et al. (2018). llustrasi model admission control ditunjukkan pada Gambar 2.

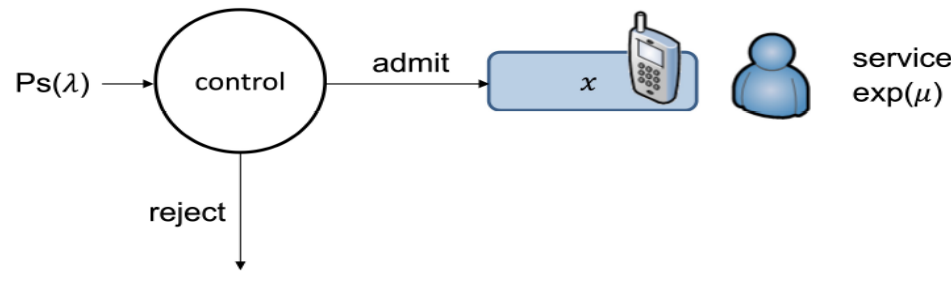

Gambar 2. Ilustrasi model admission control (Ertiningsih et al., 2018)

Gambar 2 memberikan ilustrasi mengenai model admission control di suatu sistem antrean. Sesuai dengan istilahnya yaitu admission control, model antrean ini dapat diartikan sebagai model pengaturan kedatangan pengunjung, lebih khususnya kedatangan pasien di fasilitas kesehatan. Model ini memungkinkan terjadinya penolakan (reject) pasien ketika jumlah pasien di dalam sistem sudah melebihi ambang batas (threshold) (Ertiningsih et al., 2018). Penolakan tersebut memungkinkan timbulnya suatu biaya rejection, dimana kami mengasumsikan bahwa biaya rejection adalah suatu biaya minimum yang dibutuhkan puskesmas dalam penentuan nilai threshold pasien masuk ke sistem antrean puskesmas. Ketika threshold yang ditentukan meningkat, maka biaya rejection juga meningkat. Sedangkan biaya lain yang ikut andil dalam analisis sistem adalah biaya holding atau rata-rata biaya pelayanan pasien. Berdasarkan data dari https://dprd.semarangkota.go.id/, diperoleh tarif pelayanan rawat jalan di puskesmas per kunjungan kebanyakan senilai 10.000 rupiah. Sedangkan rate kedatangan digunakan studi kasus Puskesmas Ungaran, Semarang, sebagaimana ditunjukkan dalam Tabel 1. Untuk Analisa sistem antrean dengan kontrol

Tabel 3. Parameter $\lambda, \mu, c_{r}, c_{h}$ yang digunakan dalam penelitian

\begin{tabular}{ccccc}
\hline Gambar & $\lambda$ & $\mu$ & $c_{r}$ (Rupiah) & $c_{h}$ (Rupiah) \\
\hline (i) & 0,474 & 0,526 & 100.000 & 10.000 \\
(ii) & 0,474 & 0,526 & 150.000 & 10.000 \\
(iii) & 0,474 & 0,526 & 200.000 & 10.000 \\
(iv) & 0,474 & 0,526 & 250.000 & 10.000 \\
(v) & 0,474 & 0,526 & 300.000 & 10.000 \\
(vi) & 0,474 & 0,526 & 350.000 & 10.000 \\
(vii) & 0,474 & 0,526 & 400.000 & 10.000 \\
(viii) & 0,474 & 0,526 & 450.000 & 10.000 \\
(ix) & 0,474 & 0,526 & 500.000 & 10.000 \\
(x) & 0,474 & 0,526 & 550.000 & 10.000 \\
\hline
\end{tabular}




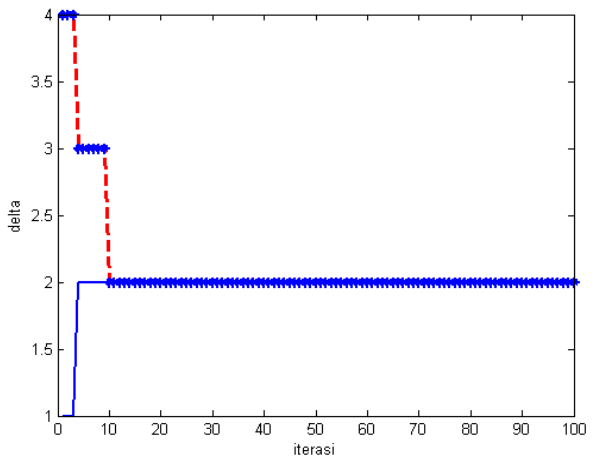

(i)

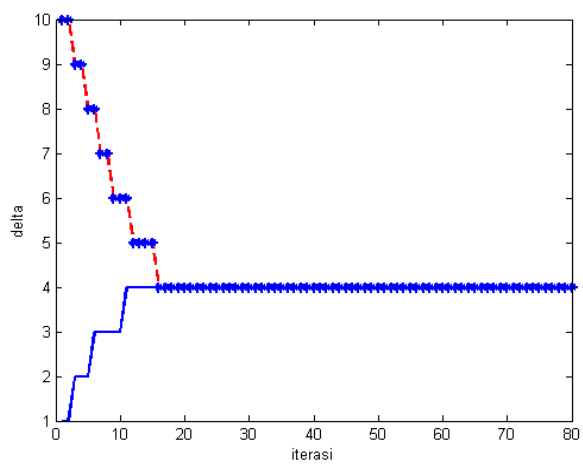

(iii)

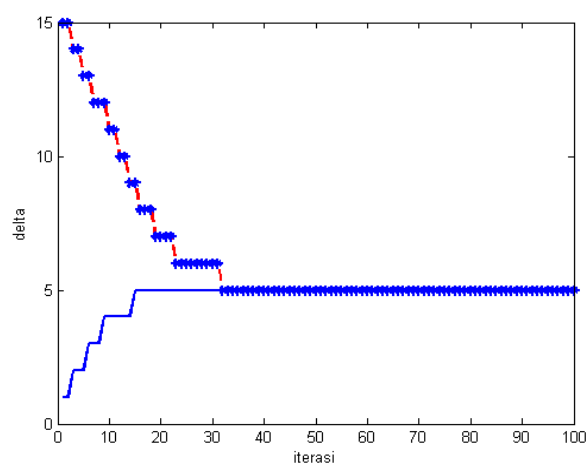

(v)

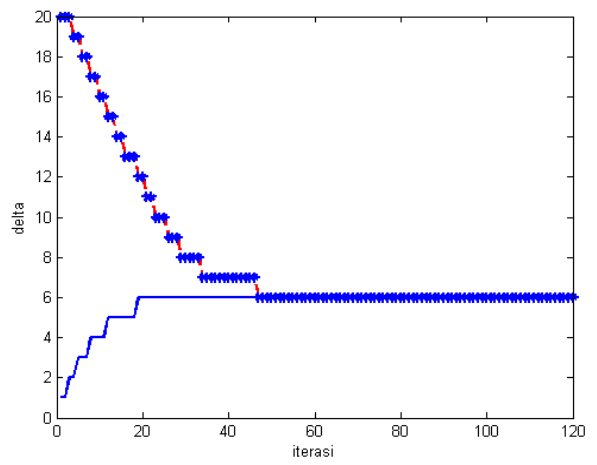

(vii)

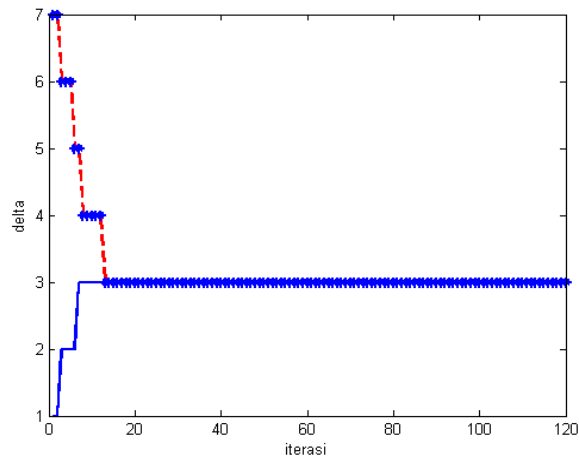

(ii)

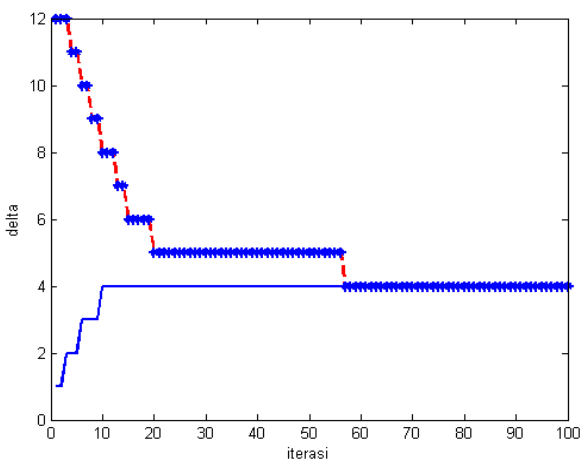

(iv)

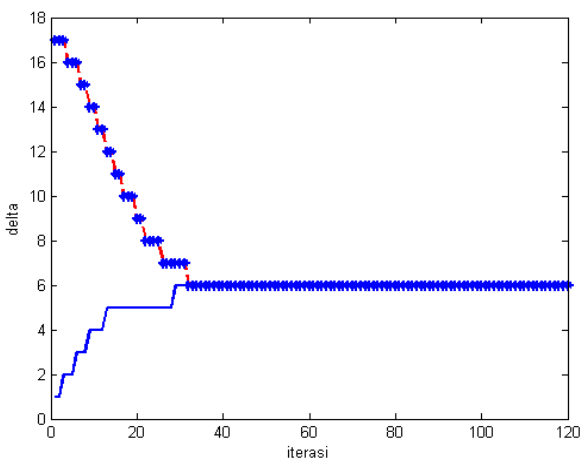

(vi)

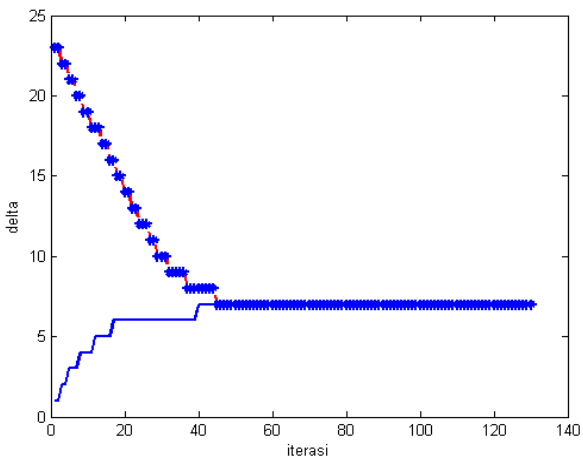

(viii)

Gambar 3. Hasil komputasi nilai $\delta$ (berlanjut)

penerimaan, dilakukan uniformisasi sedemikian rupa sehingga $\lambda+\mu=1$ (Ertiningsih et al., 2018). Parameter simulasi yang kami gunakan disajikan pada Tabel 3. Adapun hasil simulasi yang dilakukan berdasarkan Algoritma 1, Algoritma 2, Persamaan 7 sampai dengan Persamaan 12 untuk mencari nilai batasan penerimaan (threshold) pasien di Loket Puskesmas Ungaran Semarang terhadap biaya yang dibutuhkan disajikan pada Gambar 3 dan Gambar 4. 


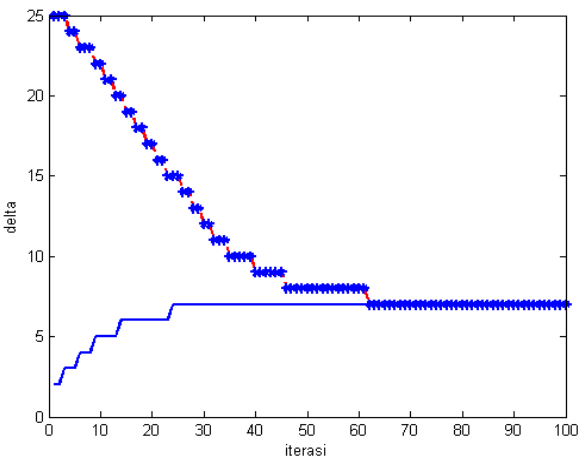

(ix)

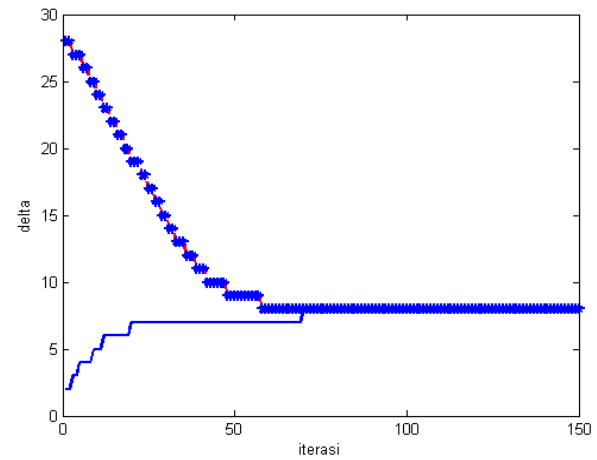

$(x)$

Gambar 4. Hasil komputasi nilai $\delta$ (lanjutan)

Gambar 3 dan Gambar 4 merupakan hasil simulasi penentuan threshold $\delta$ dari parameter input yang disajikan dalam Tabel 3. Dari (i) sampai (x) menunjukkan titik temu antara $\delta^{u}$ dan $\delta^{l}$ sehingga nilai $\delta$ bisa diperoleh, dengan demikian batas (threshold) penerimaan pasien bisa ditentukan. Semua perlakuan dalam simulasi kami rangkum dengan membandingkan batasan penerimaan pasien sebagai sumbu ordinat dan biaya yang dibutuhkan sebagai sumbu absisnya, yaitu disajikan dalam Gambar 4 pada bagian pembahasan.

\section{PEMBAHASAN}

\section{Analisis Keefektifan Sistem Antrean dengan Pertimbangan Biaya}

Penelitian ini berbeda dengan penelitian yang dilakukan oleh Robiati (2015). Dalam penelitian tersebut, analisis mengenai keefektifan sistem antrean tidak mempertimbangkan biaya. Dari penelitian tersebut disimpulkan bahwa sistem antrean yang paling efektif dengan menggunakan instrumen aplikasi WinQSB diperoleh model $\mathrm{M} / \mathrm{M} / 1$ di loket pendaftaran, model $\mathrm{M} / \mathrm{M} / 7$ di ruang dokter, dan model $\mathrm{M} / \mathrm{M} / 1$ di loket apotek dengan rata-rata jumlah pasien dalam antrean keseluruhan dan sistem keseluruhan (loket pendaftaran, ruang dokter, loket apotek) yang didapat dari $L q$ dan $L s$ adalah sebanyak lima pasien dan delapan pasien. Perihal rata-rata waktu pasien menunggu dalam antrean keseluruhan dan sistem keseluruhan yang didapat dari $W q$ dan $W s$ adalah 321,740 detik dan 738,450 detik. Sedangkan penelitian ini merupakan penelitian sistem antrean dengan pertimbangan biaya yang paling efektif. Hasil dari penelitian ini menggunakan instrumen aplikasi WinQSB yaitu sistem antrean dengan pertimbangan biaya yang paling efektif adalah model M/M/2 di loket pendaftaran dengan biaya Rp59.513, model $\mathrm{M} / \mathrm{M} / 4$ di ruang dokter dengan biaya Rp141.864, dan model M/M/1 di loket apotek dengan biaya Rp23.885. Artinya jumlah pelayan di loket pendaftaran adalah dua pelayan dengan biaya Rp59.513, di ruang dokter adalah empat pelayan dengan biaya Rp141.864, dan di loket apotek adalah satu pelayan dengan biaya Rp23.885. Ratarata jumlah pasien dalam antrean keseluruhan dan sistem keseluruhan adalah sebanyak dua pasien dan lima pasien. Perihal rata-rata waktu pasien menunggu dalam antrean keseluruhan dan sistem keseluruhan adalah 1,937 menit (atau setara dengan 116,238 detik) dan 8,883 menit (atau setara dengan 532,953 detik). Apabila hasil penelitian Robiati (2015) dibandingkan dengan penelitian penulis, maka bisa disajikan seperti pada Tabel, dimana waktu keseluruhan antrean menunjukkan rata-rata waktu pasien menunggu dalam antrean keseluruhan dan waktu keseluruhan sistem antrean menunjukkan rata-rata waktu pasien menunggu dalam sistem keseluruhan.

Tabel 4. Perbandingan model sistem antrean di Puskesmas Ungaran, Semarang

\begin{tabular}{llll}
\hline Sistem antrean & & Robiati (2015) & Penelitian \\
\hline Loket pendaftaran & Model & $\mathrm{M} / \mathrm{M} / 1$ & $\mathrm{M} / \mathrm{M} / 2$ \\
& Biaya & $\mathrm{Rp} 80.893$ & $\mathrm{Rp59.513}$ \\
Ruang dokter & Model & $\mathrm{M} / \mathrm{M} / 7$ & $\mathrm{M} / \mathrm{M} / 4$ \\
& Biaya & $\mathrm{Rp} 199.467$ & $\mathrm{Rp} 141.864$ \\
\multirow{2}{*}{ Loket apotek } & Model & $\mathrm{M} / \mathrm{M} / 1$ & $\mathrm{M} / \mathrm{M} / 1$ \\
& Biaya & $\mathrm{Rp23.885}$ & $\mathrm{Rp23.885}$ \\
\multirow{2}{*}{ Waktu keseluruhan (menit) } & Antrean & 5,362 & 1,937 \\
& Sistem antrean & 12,308 & 8,883 \\
\hline
\end{tabular}


Hasil analisis keefektifan sistem antrean pada Tabel 4 menunjukkan bahwa hasil dari penelitian ini yaitu analisis sistem antrean dengan pertimbangan biaya lebih efektif daripada analisis sistem antrean yang tidak mempertimbangkan biaya, sedemikian sehingga penelitian ini bisa menjadi bahan acuan bagi pihak puskesmas dalam mengambil keputusan atau kebijakan.

\section{Analisis Keefektifan Sistem Antrean dengan Pertimbangan Kontrol Penerimaan Pasien}

Berdasarkan hasil simulasi menggunakan aplikasi pemrograman Matlab seperti yang ditunjukkan pada Gambar 3 dan Gambar 4 dengan input parameter $\lambda, \mu, c_{r}, c_{h}$ yang diberikan pada Tabel 3, diperoleh hasil analisis keefektifan sistem antrean dengan pertimbangan kontrol penerimaan pasien seperti ditunjukkan oleh Gambar 5 .

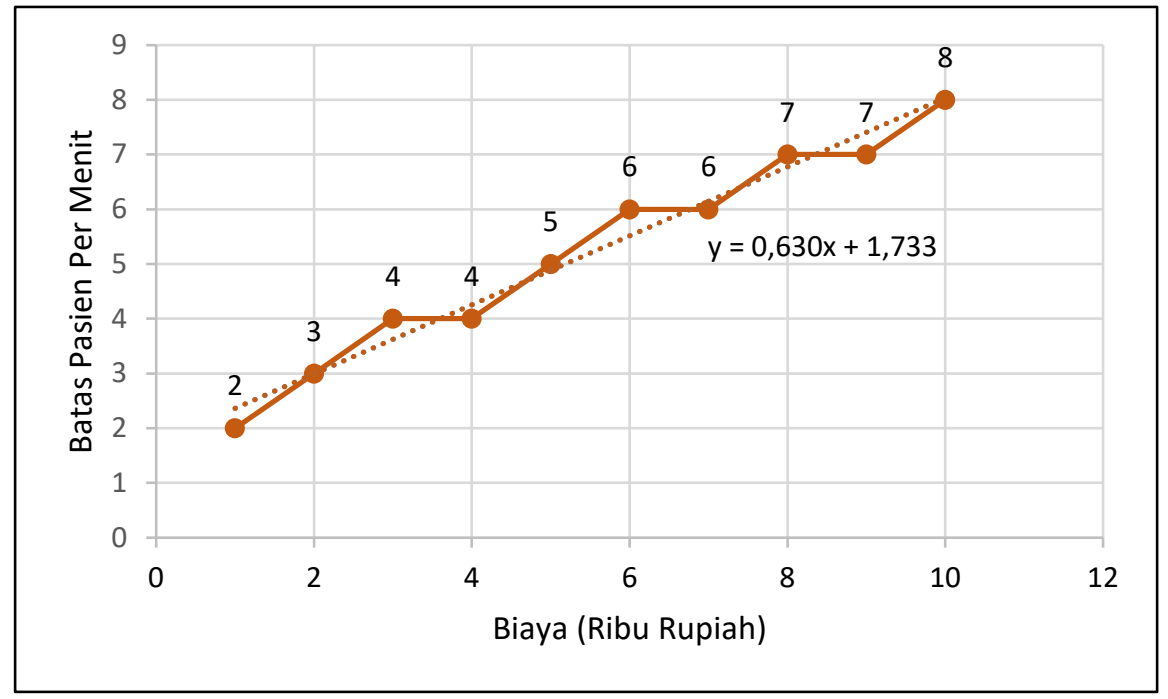

Gambar 5. Grafik batas penerimaan pasien terhadap biaya

Sebagaimana grafik yang diberikan pada Gambar 5 bahwa batas pasien yang bisa diterima di loket pendaftaran Puskesmas Ungaran, Semarang bisa didekati dengan persamaan linear berikut ini.

$$
y=0,630 x+1,733
$$

dengan $x, y$ masing-masing menunjukkan biaya yang dibutuhkan puskesmas dalam menerima pasien (dalam ribuan rupiah) dan banyaknya pasien yang diterima oleh puskesmas dalam satu menit. Dari Persamaan 13 diperoleh bahwa penerimaan pasien akan meningkat ketika biaya diperbesar. Artinya, ketika pengelola puskesmas menentukan jumlah batas penerimaan pasien, katakanlah y orang, maka biaya minimal yang perlu disiapkan adalah $x$. Sebaliknya, ketika pengelola puskesmas mempunyai dana/biaya, katakanlah $x$, maka bisa ditentukan berapa jumlah (maksimal) pasien yang dapat diterima oleh puskesmas, yaitu $y$ pasien. Selain itu, penggunaan admission control menjadikan sistem antrean mudah dikendalikan, menghemat anggaran, serta menghemat waktu mengantre.

\section{Implikasi}

Analisis keefektifan sistem antrean dengan pertimbangan biaya dapat digunakan oleh pembuat kebijakan di tempat yang memiliki antrean guna menentukan banyaknya pelayan yang dipekerjakan supaya memperoleh sistem antrean yang optimal baik dari segi waktu maupun biaya. Analisis keefektifan sistem antrean dengan pertimbangan kontrol penerimaan pasien dapat digunakan oleh pembuat kebijakan di tempat yang memiliki antrean guna menentukan batasan penerimaan pelanggan supaya memperoleh sistem antrean yang optimal baik dari segi waktu maupun biaya, serta menjadikan sistem antrean mudah dikendalikan, menghemat anggaran, serta menghemat waktu mengantre. Hasil penelitian ini dapat diteliti lebih lanjut dengan menggunakan metode analisis sistem antrean dengan pertimbangan kontrol pada pelayanan (service control).

\section{SIMPULAN}

Sistem antrean yang efektif di Puskesmas Ungaran, Semarang dengan pertimbangan biaya yaitu kedatangan pasien pada loket pendaftaran, ruang dokter, dan loket apotek menggunakan distribusi Poisson, sedangkan pelayanan pasien pada loket pendaftaran, ruang dokter, dan loket apotek menggunakan distribusi eksponensial. Kemu- 
dian, jumlah pelayan dan biaya (cost) masing-masing adalah dua pelayan dengan biaya Rp59.513 pada loket pendaftaran, empat pelayan dengan biaya Rp141.864 pada ruang dokter, dan satu pelayan dengan biaya Rp23.885 pada loket apotek. Rata-rata jumlah pasien di dalam antrean dan sistem antrean pada Puskesmas Ungaran, Semarang adalah dua pasien dan lima pasien. Sedangkan rerata waktu pasien menunggu di dalam antrean dan sistem antrean Puskesmas Ungaran, Semarang adalah 1,937 menit dan 8,883 menit. Selain itu, dari hasil analisis dengan pertimbangan kontrol penerimaan pasien, dapat ditarik kesimpulan bahwa jumlah penerimaan pasien di dalam antrean Puskesmas Ungaran, Semarang akan meningkat ketika biaya yang dibutuhkan puskesmas dalam menerima pasien (dalam ribuan rupiah) diperbesar dengan mengikuti persamaan linear $y=0,630 x+1,733$ dengan variabel $x, y$ masing-masing menunjukkan biaya yang dibutuhkan puskesmas dalam menerima pasien dan banyaknya pasien yang diterima oleh puskesmas. Hasil penelitian ini dapat ditindaklanjuti dengan melakukan penelitian lanjutkan menggunakan metode analisis sistem antrean dengan pertimbangan kontrol pada pelayanan (service control).

\section{UCAPAN TERIMA KASIH}

Ucapan terima kasih penulis sampaikan kepada Direktorat Pembelajaran dan Kemahasiswaan, Ditjen Dikti, Kementerian Pendidikan dan Kebudayaan Republik Indonesia dan Direktorat Kemahasiswaan UGM, PKM Center UGM, yang telah memberikan fasilitas penelitian berupa kegiatan PKM 2020.

\section{DAFTAR PUSTAKA}

Badan Pusat Statistik. (2020). Statistik Indonesia 2020 (Statistical yearbook of Indonesia 2020). Author.

Ertiningsih, D., Bhulai, S., \& Spieksma, F. (2018). A novel use of value iteration for deriving bounds for threshold and switching curve optimal policies. Naval Research Logistic, 65(8), 638-659. https://doi.org/10.1002/nav.21824

Heizer, J., \& Render, B. (2011). Operations management (10th ed.). Pearson.

Ibe, O. C. (2013). Markov processes for stochastic modeling (2nd ed.). Elsevier Insights.

Iqbal, M. (2011). Analisis kinerja sistem: Pendekatan teori dan praktek (Edisi kesatu). Gunadarma

Kabir, S. M. (2016). Basic guidelines for research: An introductory approach for all disciplines (1st ed.). Book Zone Publication.

Kementerian Kesehatan Republik Indonesia. (2019). Data dasar puskesmas: Kondisi 31 Desember 2018. Author. https://pusdatin.kemkes.go.id/folder/view/01/structure-data-dasar-puskesmas.html

Kementerian PPN/Bappenas. (2018). Penguatan pelayanan kesehatan dasar di puskesmas. Author. https://www.bappenas.go.id/id/profil-bappenas/unit-kerja/deputi-sdm/dit-kgm/contents-direktoratkesehatan-dan-gizi-masyarakat/penguatan-pelayanan-kesehatan-dasar-di-puskesmas/

Lakshmi, C., \& Iyer, S. A. (2013). Application of queueing theory in health care: A literature review. Operations Research for Health Care, 2(1-2), 25-39. https://doi.org/10.1016/j.orhc.2013.03.002

Mehandiratta, R. (2011). Applications of queuing theory in health care. International Journal of Computing and Business Research, 2(2), 1-11. http://www.researchmanuscripts.com/PapersVol2N2/IJCBRVOL2N2P9.pdf

Nasution, A. S., \& Mutia, S. (2017). Analisis sistem antrian pada loket pendaftaran pasien di Puskesmas Padang Pasir Kecamatan Padang Barat. Jurnal Sains dan Teknologi, 17(2), 120-125. http://dx.doi.org/10.36275/stsp.v17i2.70

Robiati, P. (2015). Analisis sistem antrian seri pada fasilitas pelayanan kesehatan dan optimalisasinya: Studi kasus di Puskesmas Ungaran, Kabupaten Semarang [Undergraduate's thesis, Universitas Negeri Semarang]. UNNES Repository. https://lib.unnes.ac.id/21606/

Sekretariat Kabinet Republik Indonesia. (2019, Maret 15). Naik per 1 januari 2019, inilah besaran gaji baru PNS. https://setkab.go.id/naik-per-1-januari-2019-inilah-besaran-gaji-baru-pns/

Shortle, J. F., Thompson, J. M., Gross, D., \& Harris, C. M. (2018). Fundamental of queueing theory (5th ed.). John Wiley \& Sons, Inc. 
PYTHAGORAS: Jurnal Pendidikan Matematika, 15 (2), 2020 - 177 Albert Hosea Santoso, Hanifa Reygina Fajrin, Akhmad Sultoni, Dwi Ertiningsih

Sofyan, D. K., Amri, A., \& Aziz, A. (2019). Penerapan sistem antrian pada fasilitas pelayanan pada fasilitas pelayanan pada loket pengembilan obat. Jurnal Optimalisasi, 5(1), 20-31. https://doi.org/10.35308/jopt.v5i1.818

Tiwari, S. K., Gupta, V. K., \& Joshi, T. N. (2015). M/M/Squeueing theory model to solve waiting line and to minimize estimated total cost. International Journal of Science and Research, 5(5), 1901-1904.

https://www.ijsr.net/get_abstract.php?paper_id=20051603

Wati, R. (2017). Sistem antrian pelayanan pasien pada Puskesmas Kelurahan Setiabudi Jakarta Selatan dengan menggunakan metode waiting line. Jurnal Techno Nusa Mandiri, 14(2), 91-96.

https://doi.org/10.33480/techno.v14i2.190 